\title{
Bimbingan Teknis Penyusunan Proposal Penelitian Tindakan Kelas dan Penulisan Artikel pada Guru-Guru Sekolah dasar di SD N 17 Limau Manis Padang
}

\author{
Mega Iswari $\left.{ }^{1 *}\right)$, Kasiyati ${ }^{2}, \&$ Zulmayetri $^{3} \&$ Arsidal $^{4}$ \\ ${ }^{1234}$ Universitas Negeri Padang \\ Đe-mail: mega_iswary@yahoo.com
}

\begin{abstract}
Abstrak
Bimbingan Teknis ini disenggarakan dalam upaya peningkatan atau pemecahan masalah dan peningkatan mutu pendidikan di berbagai bidang. Kegiatan ini diberikan kepada Guru-guru Sekolah Dasar Negeri 17 Limau Manis Padang. Guru-guru Sekolah ini merasa kurang memahami tentang Penelitian Tindakan Kelas. Setelah diberikan pelatihan/workshop tentang Penelitian Tindakan Kelas para guru yang terlibat sudah memilik pemahaman atau pengetahuan tentang pengertian penelitian tindakan kelas, karakteristik, prinsip prinsip, langkah-langkah dan alasan pentingnya penelitian tindakan kelas bagi guru di sekolah dasar. Respon guru pun cenderung positif dan menilai sangat baik, mereka mendapatkan sesuatu yang baru, hal ini terlihat dari respon positif masing-masing guru dan kepala sekolah dari Sekolah Dasar Negeri 17 Limau Manis Padang. Begitu juga pihak sekolah menyediakan waktu untuk pelaksanaan kegiatan workshop ini dan memfasilitasi tempat serta menerima kegiatan Ipteks ini dengan bersemangat, guru-guru juga mengikuti setiap sesi pelatihan dengan aktif dan antusias dalam melaksanakan kegiatan latihan mulai dari merancang proposal dan menyusun artikel hasil penelitian. Kegiatan ini perlu ditingkatkan untuk sekolah lain.
\end{abstract}

Kata Kunci: penelitian tindakan kelas penulisan artikel guru sekolah dasar

Copyright (C) 2017 IICET (Indonesia) - All Rights Reserved

Indonesian Institute for Counseling, Education and Therapy (IICET)

\section{PENDAHULUAN}

Guru-guru di Sekolah Dasar Negeri 17 Limau manis, ini merasa belum memahami tentang Penelitian Tindakan Kelas, yang selanjutnya disebut PTK, begitu pula untuk penulisan artikel. Padahal PTK dan artikel ini sangat dibutuhkan oleh guru dalam rangka pengembangan diri dan sekaligus untuk mengurus kenaikan pangkat dan kenaikan jabatan fungsional guru, di samping itu guru juga dituntut untuk selalu melakukan perbaikan perbaikan proses pembelajaran di kelas sesuai dengan kebutuhan anak. Maka dari itu dalam proses modernisasi saat ini peranan manusia sebagai guru amat menentukan, baik ditilik dari mutu maupun kemampuannya dalam memilih alternatif-alternatif yang tepat antara padat karya dan padat modal, maupun kemampuan untuk mengusahakan efisiensi dan produktifitas kerja sebagai guru.

Dalam tahap ini sumber daya manusia sebagai guru merupakan faktor yang menduduki urutan prioritas utama dalam pembangunan. Kendatipun pengembangannya tidak dapat dikatakan sederhana karena meliputi berbagai aspek pendidikan sebagai guru maupun sebagai manusia yang kemudian disusul dengan pelatihanpelatihan kerja dalam rangka meningkatkan mutu pelayanan pendidikan, namun hasil kerja guru merupakan asset yang tak ternilai bagi kemajuan bangsa di kemudian hari.

Dalam hubungan ini dirasakan adanya kebutuhan menserasikan sistem pendidikan dengan kebutuhan tenaga kerja, di mana lulusan pendidikan dapat dimanfaatkan secara optimal. Keseluruhan strategi dan langkah-langkah kebijaksanaan pengembangan kompetensi guru dan sumber daya manusia ini tidak terlepas 
dengan peranan guru selaku pemeran sentral dalam proses pendidikan, yang berarti guru harus mampu mengantarkan bangsanya ke arah modernisasi.

Semua orang yakin bahwa guru memiliki andil yang sangat besar terhadap keberhasilan pembelajaran di sekolah (Syamsuri, I. 2010; Hutasoit, T. 2011; Hidayat, M. T., \& Indonesia, K. A. R. 2012). Guru sangat berperan dalam membantu perkembangan peserta didik untuk mewujudkan tujuan hidupnya secara optimal. Keyakinan ini muncul karena manusia adalah makhluk lemah (Hulam, T. 2010) yang dalam perkembangannya senantiasa membutuhkan orang lain, sejak lahir bahkan pada saat meninggal. Semua itu menunjukkan bahwa setiap orang membutuhkan orang lain dalam perkembangannya, demikian halnya peserta didik, ketika orang tua mendaftarkan anaknya ke sekolah pada saat itu juga ia menaruh harapan terhadap guru, agar anaknya dapat berkembang secara optimal.

Minat, bakat, kemampuan dan potensi-potensi yang dimiliki oleh peserta didik tidak akan berkembang secara optimal tanpa bantuan guru. Guru juga harus berpacu dalam pembelajaran, dengan memberikan kemudahan belajar bagi seluruh peserta didik agar dapat mengembangkan potensinya secara optimal.

Dalam proses pendidikan, pendidik atau guru memegang peran yang sangat penting dan menentukan dalam mencapai tujuan pendidikan. Pendidik merupakan orang dewasa baik secara kodrati (orang tua) maupun secara profesi (menjadi pedidik karena tugas jabatan) bertanggung jawab dalam menumbuh kembangkan anak didik.Oleh sebab itulah pemerintah menaruh perhatian sungguh-sungguh dalam pembinaan dan kemampuan guru, mengingat peranan guru yang sentral dalam upaya mencerdaskan kehidupan bangsa

Dengan demikian maka peningkatan mutu guru merupakan urgensi, sebabwalaupun usaha peningkatan mutu pendidikan disekolah tergantung dari berbagai faktor, namun faktor utamanya ialah guru memiliki kompetensi yang bermutu, yang memliki sarana yang lengkap, sistem yang memadai niscaya akan menghasilkan manusia yang berkualitas, manusia yang unggul, kreatif, trampil dan inovatif. Hal ini sangat penting terutama dalam menghadapi tinggal landas dan era globalisasi, sebab kecenderungan dunia telah memberikan bukti bahwa kekayaan sumber alam relatif akan semakin berkurang peranannya, jika dibandingkan dengan kualitas sumber daya manusia didalam mewujudkan cita-cita bangsanya.

Guru yang professionalmemiliki keahlian, tanggung jawab, dan rasa kebersamaan yang didukung oleh etika profesi yang kuat.Untuk itu diharapkan guru telah memiliki intelektual sosial, spiritual, pribadi, moral dan profesional, agar guru dapat berkembang kearah penguasaan-penguasaan kompetensi profesional sebagai landasan kerja.Unjuk kerja guru pada dasarnya merupakan perwujudan profesionalitas para guru secar sadar dan terarah untuk melaksanakan pendidikan baik di sekolah maupun diluar sekolah. Dengan demikian guru yang profesional ialah mereka yang memiliki keahlian baik yang menyangkut materi keilmuan yang dikuasai maupun keterampilan metodologinya dimana keahlian yang dimiliki oleh guru yang profesional diperoleh melalui suatu proses pendidikan dan latihan yang di programkan dan terstruktur secara khusus.

Sehubungan dengan adanya perubahan-perubahan dalam dunia pendidikan sebagai penyesuaian pendidikan terhadap tuntutan yang terus berkembang, terjadi pula inovasi di dalam proses belajar mengajar, yang menyebabkan perubahan dalam peranan guru dan penempatan tanggung jawab pada murid. Pendidikan yang semula lebih didasarkan kepada mengingat, lambat laun diganti dengan metode untuk mengembangkan kemampuan siswa dalam pengamatan, analisa dan penalaran reasoning inilah hakikat belajar mengajar yang sebenarnya.

Sebagai pendidik, guru memiliki tugas yang harus dilakukan secara profesional, tugas guru tersebut diantaranya yaitu mendidik, mengajar dan melatih anak didik adalah tugas guru sebagai suatu profesi. Tugas guru sebagai pendidik berarti meneruskan dan mengembangkan nilai-nilai hidup kepada anak didik.Tugas guru sebagai pengajar berarti meneruskan dan mengembangkan ilmu pengetahuan dan teknologi kepada anak didik. Tugas guru sebagai pelatih berarti mengembangkan keterampilan dan menerapkannya dalam kehidupan demi masa depan anak didik.

Perubahan dalam peran guru ini sudah tentu menumbuhkan perubahan dalam latihan dan pendidikan guru guna memperoleh guru dengan kemampuan profesional yang tinggi.Kualitas standar pendidikan permulaan seorang guru, secara berangsur-angsur telah berubah yaitu setingkat universitas.Sedangkan pendidikan dalam jabatan (inservice training) merupakan bagian yang tak terpisahkan dari pembinaan guru 
untuk memajukan mereka dalam pengetahuan bidang studi dasar serta untuk membiasakan diri dengan tehnik pengajaran baru.

Perkembangan ilmu pengetahuan dan teknologi sejak pertengahan kedua abad ke 20 jauh lebih pesat dari pada era sebelumnya.Kenyataan ini ditambahkan dengan majunya sistem komunikasi yang menghadapkan guru kepada banyak pilihan sumber bahan untuk dijadikan objek belajar para siswanya. Pilihan tersebut meliputi jenis pokok bahasan yang perlu dipilih. Oleh karena itu guru dituntut memiliki kemampuan untuk memilih di antara berbagai alternatif pilihan yang paling relevan dengan fungsi, tujuan pendidikan serta tingkat kemampuan dan perkembangan peserta didik.

Perubahan tujuan dan fungsi pendidikan sekolah yang lahir karena perubahan tuntutan masyarakat yang terus berubah serta perkembangan iptek yang pesat ditambah dengan heterogenitas populasi peserta didik menuntut tenaga guru dengan kualifikasi profesional. Guru profesional tidak hanya dituntutuntuk dapat menyampaikan informasi kepada peserta didik, melainkan dituntut pula merencanakan, mengelola, mendiagnosis, dan hasil proses belajar.Menurut Roestiyah N.K dalam Djamarah (2010 : 34-36) tugas seorang guru dalam mendidik anak yaitu: a) Menyerahkan kebudayaan kepada anak didik berupa kepandaian, kecakapan dan pengalaman-pengalaman, b) Membentuk kepribadian anak yang harmonis, sesuai cita-cita dan dasar negara kita PancasilaMenyiapkan anak menjadi warga negara yang baik sesuai Undang-undang Pendidikan yang merupakan keputusan MPR No. II Tahun 1983., c) Sebagai perantara dalam belajar, d) Guru adalah sebagai pembimbing, untuk membawa anak didik ke arah kedewasaan, pendidik tidak maha kuasa, tidak dapat membentuk anak menurut sekehendaknya, e) Guru sebagai penghubung antara sekolah dan masyarakat, f) Sebagai penegak disiplin, guru menjadi contoh segala hal, tata tertib dapat berjalan bila guru dapat menjalani lebih dahulu, g) Guru sebagai administrator dan manajer, h)Pekerjaan guru sebagai profesi, i) Guru sebagai perencana kurikulu, J) Guru sebagai pemimpin, k) Guru sebagai sponsor dalam kegiatan anakanak.

Peningkatan profesional guru hendaknya dilaksanakan secara terpadu melalui berbagai pelaksanaan tugas baik secara langsung maupun tidak langsung.Ini merupakan upaya peningkatan profesionalisme, kegiatan ini sangat terkait dengan kegiatan sehari-hari.Seperti guru-guru melaksanakan kerja kelompok dan diskusi kelompok dalam rangka memecahkan masalah.

Kegiatan serupa ini dapat dilakukan oleh guru pada saat pelaksanaan MGMP (Musyawarah Guru Mata Pelajaran). Ini merupakan suatu wadah bagi guru untuk saling bertukar pengetahuan dan pengalaman, sehingga diharapkan setelah kegiatan MGMP dapat mengembangkan dan meningkatkan wawasan untuk menuju guru yang profesional.

Secara garis besar pembinaan guru selaku aparatur negara meliputi pengembangan profesional, peningkatan kesejahteraan dan pengelolaan administrasi kepegawaian. Peningkatan profesional diarahkan pada peningkatan moral dan etika, kemampuan serta pengembangan ilmu, sehingga semakin lama terdapat peningkatan kemampuan guru dalam melaksanakan tugas kependidikan dan tugas pembangunan. Penyempurnaan pengelolaan administrasi kepegawaian diarahkan kepada kemampuannya untuk mendukung kegiatan pembinaan pegawai sehingga pengendalian dan pengawasan pembinaan dapat terlaksana dengan efektif (Bulan, S. G. I., Tinangon, J. J., \& Mawikere, L. 2017; Bharoto, R. M. H. 2016; Palupi, S. 2006). Penyempurnaan pengelolaan administrasi kepegawaian telah dirasakan sebagai kebutuhan yang mendesak, karena hambatan dalam kenaikan pangkat telah mengakibatkan menurunnya kegairahan kerja. Peningkatan profesional tidak secara otomatis menghasilkan peningkatan produktifitas, apabila tingkat kesejahteraan tidak baik. Bahkan peningkatan profesionalisasi tanpa diimbangi dengan perbaikan kesejahteraan dapat menjurus ke arah in efisiensi, kerena tenaga ini lebih banyak menggunakan waktunya untuk melaksanakan tugas di luar dinas. Ini berarti pemahaman investasi dalam sumberdaya manusia akan sia-sia belaka.

Dalam rangka meningkatkan profesionalisme guru telah ditetapkan keputusan nomer 26/Mempan/1989 yang selanjutnya disempurnakan dengan keputusan nomer 084/1993 tentang jabatan fungsional guru dan angka kreditnya. Keputusan ini mengandung dua tujuan yakni;1)meningkatkan mutu serta kemampuan guru, 2) meningkatkan kualitas pendidikan. Peningkatan profesional pembinaannya dimulai sejak saat seseorang diterima menjadi Pegawai Negeri Sipil untuk diarahkan pada bidang keahlian tertentu.Pembinaan selanjutnya adalah melalui pendidikan dan latihan yang disesuaikan dengan jabatan. 
Dalam keadaan ini perlu dikemukan bahwa kemampuan profesional menuntut pendidikan dan latihan khusus. Guru adalah jabatan profesional, karena tugas guru pada hakikatnya adalah tugas /pekerjaan yang hanya dapat dilakukan oleh orang yang secara khusus telah mengikuti pendidikan dan latihan khusus pada tingkat pendididkan tinggi. Oleh karena itu, kualifikasi seorang guru saat ini telah banyak yang berlatar pendidikan S1, S2 dan bahkan ada yang S3 untuk guru SLTA. Sedangkan latihan khusus untuk guru dilakukan melalui berbagai kegiatan pelatihan dan penataran yang terencana dan sistimatis serta latihan profesional lain seperti kelompok-kelompok kerja guru.

Dalam UU Sisdiknas Nomer 14 tentang guru dan dosen pasal 10 menyatakan bahwa guru harus memiliki kompetensi pedagogik, kompetensi kepribadian, kompetensi profesional dan kompetensi sosial. hal ini harus mampu diterapkan oleh guru dalam kegiatan pendidikan dan pengajaran di sekolah maupun di masyarakat. Guru di sekolah yang sangat penting dilakukan adalah selalu memperbaiki proses pembelajaran melalui Penelitian Tindakan Kelas.

Menurut Stephen Kemmis, 1983(dalam David Hopkins, 1993:44).PTK atau action research adalah suatu bentuk penelaahan atau inkuiri melalui refleksi diri yang dilakukan oleh peserta kegiatan pendidikan tertentu dalam situasi sosial (termasuk pendidikan) untuk memperbaiki rasionalitas dan kebenaran dari (a) praktikpraktik sosial atau pendidikan yang mereka lakukan sendiri, (b) pemahaman mereka terhadap praktik-praktik tersebut, dan (c) situasi di tempat praktik itu dilaksanakan.

Menurut Aqib (2007:13) ada beberapa alasan mengapa PTK merupakan suatu kebutuhan bagi guru untuk meningkatkan profesionalisme seorang guru, antara lain: (1) PTK sangat kondisif untuk membuat guru menjadi peka dan tanggap terhadapa dinamika pembelajaran di kelasnya. Para guru menjadi reflektif dan kritis terhadap apa yang ia dan muridnya lakukan (2) PTK dapat meningkatkan kinerja guru sehingga menjadi professional. Guru tidak lagi sebagai seorang prktisi, yang sudah merasa puas terhadap apa yang dikerjakan selama bertahun-tahun tanpa adanya upaya perbaikan dan inovasi, namun juga sebagai peneliti di bidangnya.(3) Dengan melaksanakan tahapan-tahapan PTK, guru mampu memperbaiki proses pembelajaran melalui suatu kajian yang dalam terhada apa yang terjadi di kelasnya. Tindakan yang dilakukan oleh guru semata-mata didasarkan pada masalah actual dan factual yang berkembang di kelasnya. (4) Pelaksanaan PTK tidak menganggu tugas pokok seorang guru karena dia tidak perlu meninggalkan kelasnya. PTK merupakan suatu kegiatan penelitian yang terintegrasi dengan pelaksanaan proses pembelajaran.(5) Dengan melaksanakan PTK guru menjadi kreatif karena selalu dituntut untuk melakukan upaya-upaya inovasi sebagai implementasi dan adaptasi berbagai teori dan teknik pembelajaran serta bahan ajar yang dipakainya. Dalam setiap kegiatan, guru diharapkan dapat mencermati kekurangan dan mencari berbagai upaya sebagai pemecahan.

Berdasarkan alasan yang dikemukakan Aqib seperti yang disebutkan di atas, jelaslah bahwa pelaksanaan PTK sangat penting bagi seorang guru dalam rangka peningkatan profesionalismenya sebagai seorang pendidik. Selain itu, yang menjadi tujuan utama PTK adalah untuk peningkatan layanan professional guru dalam menangani proses belajar mengajar (Abdullah, A. G., \& Ridwan, T. 2008; Susilana, R. 2002; Sumini, T. 2005), yang mana tujuan itu dapat dicapai dengan melakukan refleksi untuk mendiagnosis keadaan, lalu kemudian mencoba secara sistematis sebagai tindakan alternative dalam memecahkan permasalahan pembelajaran di kelas dan/atau implementasi program sekolah yang sedang dirasakan.

Penelitian Tindakan Kelas (PTK) hendaknya dikuasai oleh semua guru, karena PTK merupakan salah satu indikator dalam peningkatan profesional guru, juga dapat memotivasi guru untuk selalu berfikir kritis dan sistematis untuk memajukan proses pembelajaran di sekolah. selain itu PTK bertujuan untuk memperbaiki proses pembelajaran secara terus menerus dan berkesinambungan pada setiap siklus yang mencerminkan terjadinya peningkatan atau perbaikan.

Artikel ilmiah adalah karya tulis yang dirancang untuk dimuat dalam jurnal ilmiah yang ditulis dengan tata cara ilmiah (Muninjaya, P. D. A. G. 2002; Manullang, J. 2017; Sari, N. M. I. 2016). Artikel hasil penelitian berisikan hal-hal penting saja (Sulistio, O. 2014; Wahdaniah, W. 2016) yang mencangkup temuan penelitian pembahasan penelitian. sistematika punulisannya terdiri atas bagian dan sub bagian. Judul artikelhendaknya informatif lengkap, tidak terlalu panjang dan tidak terlalu pendek dan ditulis dengan huruf kapital, nama penulis ditulis atau diikuti gelar akademik. Tujuan penulisan karya ilmiah yaitu meyakinkan 
pembaca bahwa topik yang ditulis memang perlu diketahui dan diperhatikan; membahas suatu permasalahan; menjelaskan suatu gejala; mengemukakan ide, gagasan, pikiran, pendapat untuk pemecahan masalah.

Ciri-ciri penulisan karya ilmiah yaitu objektif, tidak memihak, berdasarkan fakta, sistematis, praktis, logis, dan ditulis dalam bahasa yang baik dan benar (EYD); masalah atau topik yang dibahas, kejelasan tujuan pembahasan, kelogisan pembahasan, dan kejelasan pengorganisasian pembahasannya

Berdasarkan studi pendahuluan yang dilakukan ternyata guru-guru di Sekolah Dasar Negeri 17 Limau Manis ternyata masih banyak yang belum mengerti cara pelaksanaan penelitian tindakan kelas dan bahkan masih ada yang belum mendapatkan pelatihan tentang Penelitian Tindakan Kelas. Hal ini yang membuat tim pengabdian ingin berbagi ilmu bagi guru-guru dalam rangka memperbaiki kinerja atau permasalahan yang terjadi dalam pengajaran di kelas. sekaligus untuk meningkatkan keprofesionalan guru dalam memperbaiki proses pembelajaran di kelas. Berdasarkan permasalahan di atas, maka perlu dilakukan suatu kegiatan yang terencana dan sistimatis untuk melatih guru dalam memahami penelitian tindakan kelas.

\section{METODOLOGI}

Untuk mengatasi permasalahan dari guru-guru terkait dengan penulisan proposal PTK dan penulisan artikel, maka materi dari bimbingan teknis ini adalah sebagai berikut : (1) Konsep dasar tentang Penelitian Tindakan Kelas (2) Tujuan Penelitian Tindakan Kelas (3) Langkah penyusunan Penelitian Tindakan Kelas (4) Langkah pelaksanaan Penelitian Tindakan Kelas (5) Penyusunan laporan Penelitian Tindakan Kelas (6) Teknik penulisan Artikel (7) Pelatihan penulisan proposal PTK kemudian dilanjutkan dengan penulisan artikel. Selesai pelatihan guru-guru disarankan untuk menyelesaikan artikelnya dengan bimbingan pelaksana IbM melalui on linedan dibantu untuk bisaditerbitkan di jurnal ilmiah.

\section{HASIL DAN PEMBAHASAN}

Pelaksanaan kegiatan Ipteks dilaksanakan selama tiga hari yaitu hari sabtu dan hari Minggu tanggal 29 dan 30 Juli 2017, bertempat di sekolah dasar negeri 17 Limau Manis Padang. Kegiatan ini diikuti oleh guru sebanyak 15 orang yang memberikan pelatihan adalah tim pengabdian yang berjumlh 4 orang. Pada hari pertama yaitu Sabtu tanggal 29 Juli 2017 di mulai pada pukul 08.30 WIB dengan melakukan registrasi peserta oleh panitia. Pukul 09.00 WIB, acara dibuka oleh MC dan pembacaan ayat suci Al-quran oleh mahasiswa PLB. Acara dilanjutkan oleh sepatah kata dari ketua pelaksana yaitu Prof. Dr .Mega Iswari, M.Pd dan sekaligus membuka acara pelatihan secara resmi, serta perkenalan peserta dan narasumber yang selesai pada pukul 10.00. Selesai kata sambutan dilanjutkan dengan istirahat sebentar sambil menikmati snack yang disediakan yaitu padapukul 10.00 sampai 12.00. Acara dilanjutkan dengan kegiatan sesi pertama oleh nara sumber Prof Dr Mega Iswari, M.Pd. materi yang disampaikan tentang penjelasan Penelitian Tindakan Kelas sampai pukul 14.30. Pukul 14.30 sampai pukul 15.30 isoma, yaitu istirahat shalat dan makan. Acara dimulai untuk kegiatan sesi kedua yaitu pukul 15.30 sampai pukul 17.30 WIB dengan nara sumber Prof Dr Mega Iswari, M.Pd dan Tim pengabdian materi yang disajikan tentang latihan merancang proposal PTK.

Hari kedua Minggu tanggal 30 Juli 2017 kegiatan pengabdian dimulai pukul 09.00 pagi kegiatan dimulai dengan menentukan masalah dan membuat judul yang dilakukan oleh semua peserta, selanjutnya guru-guru atau peserta diminta merancang proposal PTK yang didampingi oleh nara sumber Tim Pengabdian, kegiatan yang dilakukan yaitu melatih dan membimbing guru-guru dalam merancang proposal PTK untuk memperbaiki proses dan mutu pembelajaran siswa yang mereka ajar di kelasnya masing-masing kemudian pelatihan penulisan artikel yang dibimbing oleh Dra Zulmiyetri, M.Pd.. Pukul10.00 sampai pukul 10.45 istirahat. Kegiatan dimulai lagi pukul 10.45 WIB kegiatan di mulai dengan tanya jawab tentang penyelenggaraan pelatihan dan sejauh mana mereka menguasai tentang materi yang telah disampaikan dan harapan-harapan guru tentang pelaksanaan PTK di Sekolah kemudian menyusun karya ilmiah. Pukul 12.3014.00 ISOMA yaitu istirahat, sholat, makan. Pukul 14.00-15.30 WIB, kegiatan ditutup oleh ketua pelaksana.Untuk lebih jelasnya pelaksanaan kegiatan dapat dilihat pada lampiran. Pada hari ketiga Sabtu tanggal 19 Agustus 2017 melakukan review atau pengecekan proposal dan jurnal yang telah dirancang guru. Dan hari ke empat hari Minggu tanggal19 Agustus 2017 melakukan review atau pengecekan proposal dan jurnal yang telah dirancang guru. 
Adapun hasil penilaian terhadap pelaksanaan Ipteks ini pada guru-guru sekolah dasar negeri 17 Limau Manis menunjukkan : a) Guru di sekolah ini baru dua orang yang telah melakukan Penelitian Tindakan Kelas yaitu satu orang guru tetap (PNS) dan satu orang guru Honorer, sedangkan beberapa guru-guru yang lain belum pernah membuat proposal dan melakukan Penelitian Tindakan Kelas dalam rangka memperbaiki proses pembelajaran, sehingga guru-guru belum memahami untuk melaksanakan Penelitian Tindakan Kelas, Melalui latihan ini guru-guru sangat antusias untuk mengikutinya. Karena materi tersebut mudah dipahami bagi mereka. b) Semua Peserta yang mengikuti pelatihan merasa senang dan lebih memahami tentang PTK serta termotivasi bahkan tidak ada yang mengantuk, di hari ke dua semua guru tetap menghadiri pelatihan ini, yang kegiatannya diisi dengan kiat-kiat penulisan jurnal dan attikel hasil penelitian. Dalam rangk mengetahui sejauh mana pelatihan dalam menyusun proposal PTK dan kiat-kiat penulisan artikel hasil penelitian. Guru dapat dikatakan berhasil, baik secara teknis maupun manfaat yang diperoleh peserta, diadakan penilaian tentang hal sebagai berikut: 1) Dalam kegiatan ini semua peserta atau guru mampu merancang PTK sesuai dengan proses pembelajaran di kelasnya masing-masing, 2) Semua guru atau peserta pelatihan mampu melaksanakan PTK sesuai dengan langkah-langkah PTK yang sesuai dengan siklusnya, dan 3) Semua guru atau peserta mampu membuat artikel dari hasil penelitian yang telah dilakukan.

\section{SIMPULAN DAN SARAN}

Setelah dilakukan kegiatan pelatihan PTK dan penulisan artikel hasil penelitan pada guru-guru di Sekolah Dasar Negeri 17 Limau Manis Padang, guru-guru memahami tata cara penyusunan proposal PTK melaksanakan PTK dan memahami tata cara menulis artikel hasil penelitian. Kegiatan ini terlaksana dengan baik dan lancer, hal ini terlihat dari cara guru menyususn/merancang proposal dengan serius. Secara khusus hasil dari kegiatan pelatihan ini dapat disimpulkan sebagai berikut : a) Pelatihan yang dilaksanakan sangat berdampak positif pada guru dan memberikan manfaat yang sangat besar dalam mengembangkan profesionalismeguru, sehingga guru memiliki pengetahuan dan keterampilan tentang: karakteristik Penelitian Tindakan Kelas, Tujuan Penelitian Tindakan Kelas, Memahami konsep dan langkah-langkah PTK, Menyusun atau merancang PTK. Melaksanakan PTK di dalam kelas, menyusun artikel hasil penelitian. b) Pelatihan penyusunan proposal PTK, pelaksanakan PTK dan penyusunan artikel hasil penelitian memperbaiki proses pembelajaran dan mengembangkan semangat guru-guru untuk melakukan Penelitian Tindakan Kelas, untuk melakukan inovasi dalam pembelajaran,guru menjadi percaya diri mencoba hal baru yang dapat membawa perubahan dalam proses pembelajaran. c) Tanggapan guru-guru terhadap pelatihanini dinilai baik, terbukti dari kahadiran yang disiplin dari awal sampai akhir, mengikuti setiap sesi pelatihan dengan aktif dan antusias dalam melaksanakan kegiatan praktek secara maksimal.

Berdasarkan hasil pelatihan yang telah diberikan kepada guru-guru di sekolah tersebut, disarankan sebagai berikut: 1) Semuaguru yang mengikuti pelatihan ini hendaknya dapat merancang dan melaksanakanPTK. 2) Semua guru mampu membuat artikel hasil penelitian yang bisa dimuat dalam jurnal pendidikan. 3) Kepala sekolah hendaknya menyuruh guru-guru di sekolah untuk melaksanakan PTK dan memfasilitasi guru dengan sarana prasarana pembelajaran yang dibutuhkan di sekolah.

\section{DAFTAR RUJUKAN}

Abdullah, A. G., \& Ridwan, T. (2008). Implementasi Problem Based Learning (PBL) pada Proses Pembelajaran di BPTP Bandung. Prosiding UPI, 1-10.

Aqib, Zainal. (2007). Penelitian Tindakan Kelas. Bandung: Yrama Media.

Bharoto, R. M. H. (2016). Pengaruh Perencanaan Dan Pengawasan Terhadap Efektivitas Pengelolaan Air Minum Di Perusahaan Daerah Air Minum Kota Cirebon. Publika, 1(2).

Bulan, S. G. I., Tinangon, J. J., \& Mawikere, L. (2017). Pengaruh Kualitas Pengelola Keuangan dan Sistem Pengendalian Intern Pemerintah (SPIP) terhadap Efektivitas Pengelolaan Keuangan Daerah pada Inspektorat Pemerintah Kota Manado. Jurnal Riset Akuntansi Going Concern, 12(01).

Creswell J.W. (1994). Research Design: Qualitative and Quantitative Approaches, Sage Publication, Thousen Oaks.

Hidayat, M. T., \& Indonesia, K. A. R. (2012). Kemampuan guru dalam mengelola kelas dan pengaruhnya terhadap prestasi belajar siswa pada mata pelajaran ips di mts nu astanajapura kabupaten cirebon.

Hopkins, D. (1993). A Teacher's Guide to Classroom Recearch. Philadelphia: Open University Press.

Hulam, T. (2010). Jaminan Dalam Transaksi Akad Mudharabah Pada Perbankan Syariah. Mimbar Hukum, $22(3), 520-533$. 
Hutasoit, T. (2011). Pengaruh iklim organisasi, kepuasan kerja dan motivasi berprestasi terhadap kinerja guru: studi empiris di SMP Negeri Kecematan Sipoholon Kabupaten Tapanuli Utara (Doctoral dissertation, UNIMED).

Manullang, J. (2017). Membangun Daya Nalar dalam Penulisan Artikel Ilmiah. Generasi Kampus, 7(1).

Muninjaya, P. D. A. G. (2002). Langkah Langkah Praktis Penyusunan Proposal dan Publikasi Ilmiah. EGC.

Nana Sudjana\& Ulung Laksamana. 2001. Menyusun Karya Tulis Ilmiah Untuk Memperoleh Angka Kredit. Bandung: Sinar baru Algesindo.

Palupi, S. (2006). Peranan pengawasan dalam meningkatkan efektivitas kerja pegawai di dinas pariwisata seni dan budaya kota Surakarta tahun 2006 (Doctoral dissertation, Universitas Sebelas Maret).

Sari, N. M. I. (2016). Betacyanin Assays of Fruit Beet (Beta Vulgaris L.) with Solvent Ethanol as a Biology Learning Object Material. Indonesian Journal of Biology Education, 2(1).

Sulistio, O. (2014). Penerapan Kode Etik Jurnalistik dalam Penulisan Judul Berita Di Surat Kabar Harian Pekanbaru MX (Doctoral dissertation, Universitas Islam Negeri Sultan Sarif Kasim Riau).

Sumini, T. (2005). Penelitian Tindakan Kelas dan Pengembangan Profesi Guru. Universitas Sanata Dharma. Yogyakarta.

Susilana, R. (2002). Penelitian Tindakan Kelas.

Syamsuri, I. (2010). Peningkatan Kompetensi Guru untuk Meningkatkan Minat Siswa pada Bidang MIPA. Makalah disampaikan dalam Lokakarya MIPAnet.

Wahdaniah, W. (2016). Pemakaian Bahasa dalam Jurnal Teknologi Politeknik Negeri Lhokseumawe. Jurnal Metamorfosa, 3(1). 